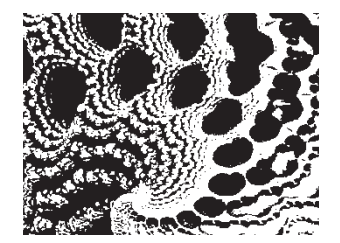

\title{
HOW INTERNAL IMMIGRATION CAN AFFECT INCOME INEQUALITY: THE ITALIAN CASE FROM AN ECONOMIC AND JURIDICAL PERSPECTIVE
}

Salvatore VILLANI, Luigi FERRARA, Giorgio LIOTTI

University of Naples Federico II, Naples, Italy

UDK: $331.556 .2(450)$

$314.15(450): 34$

Izvorni znanstveni rad

Primljeno: 16. 9. 2015.

Earlier version was presented at the 11 th International Conference: "Challenges of Europe: Growth Competitiveness and Inequality", Split/Hvar May 2015, organized by University of Split, Faculty of Economics.

A number of scholars are currently arguing that migration may have an important role in the reduction of inequality. It has happened before and it may also happen in the future, as it is possible and desirable. However, migration in itself does not resolve the issue of inequalities. At most, it would shift it forward, because redistribution through immigration does not exempt from previously creating a basic set of rules and institutions aimed at stimulating a major cooperation by countries to change the legal management systems of migration and correct their redistributive effects. In light of these studies, the present paper focuses on the regional impact of internal migration and attempts to demonstrate, with reference to the Italian case, how out-migration can increase income inequalities, thus hindering economic growth, while immigration can reduce income inequalities and mitigate economic imbalances. From a juridical point of view, we study the regional restrictions related to residence workers protection, the free movement of European workers and the welfare benefits for migrants.

Keywords: income inequality, migration, redistribution through immigration, administrative citizenship for migrants

$\triangle$ Salvatore Villani, University of Naples Federico II, Department of Political Science, Via L. Rodinò, 22, 80138 - Naples, Italy.

E-mail: salvatore.villani@unina.it 


\section{INTRODUCTION AND EXECUTIVE SUMMARY}

\section{Migration and inequality: A brief review of the literature}

The phenomenon of migration has been studied in depth by researchers from various disciplines (geographers, demographers, sociologists, economists, law scholars), both from a theoretical and empirical point of view. In the economic field, numerous studies have analysed its causes, categorisations and effects, especially those influencing the labour market, public finances and the economic growth process. ${ }^{1}$ With regard to the effects of the phenomenon, economic literature has shown that immigration allows a more efficient allocation of resources and, in this way, an improvement of the social welfare. This improvement, however, has often been considered insignificant or, otherwise, of very small scale. For this reason, the economic debate has focused on issues which concern principally the redistributive impact of immigration, rather than its allocative efficiency.

A significant part of the literature has focused on the relationship between the mobility of the production factor labour and the inequalities in the income and wealth distribution. In fact, it is generally accepted that the migratory phenomenon is closely connected to issues of inequality, considered in its widest meaning. ${ }^{2}$ Consequently, a remarkable amount of studies have examined this kind of effect, focusing their attention on several types of migration and inequality. ${ }^{3}$

Some of these studies have mainly analysed the impact of out-migration from the source rural areas of poor or developing countries on various measures of inequality and concluded (cf. Todaro, 1968, 1969, 1971; Harris \& Todaro, 1970; Johnson, 1971) that rural-urban migration often works as a "rebalancing force which equalises the expected wages of urban and rural areas". This would occur, according to the famous model of Harris and Todaro (1970), because the expected income gaps between urban and rural areas are one of the reasons (determinants) why the decision to migrate is made. Subsequent studies (Lipton, 1980) have shown, in fact, that income inequality is a leading cause for rural-urban migration ${ }^{4}$ and that it is in turn influenced by migration flows towards the cities (townward emigration), as well as by their "aftereffects" (remittances and so-called "return migration"). Regarding this issue, Lipton's analysis relating primarily, but not exclusively, to the urban and rural areas of India is particularly enlightening. It shows that these phenomena can result in an increase in inequality among individuals and among families within and among villages. 
DRUŠ. ISTRAŽ. ZAGREB GOD. 25 (2016), BR. 4 STR. $455-480$

VILLANI, S., FERRARA, L., LIOTTI, G.:

HOW INTERNAL..
Thereafter, additional studies have in many cases confirmed Lipton's theories, but many others have also led to different conclusions (cf., among others, Stark, Taylor, \&Yitzhaki, 1986; Taylor, 1992, regarding this issue). One of the reasons for these differences is due to the diversity in the research methodologies adopted (the specific economic issue which has been proposed, the statistical and econometric techniques utilised for estimating the income and the income distributions and so on). For example, if the remittances are considered as an exogenous variable, which is not affected by a retro-effect due to economic growth (which should be considered as determined by and, at the same time, a determinant of the remittances) the economic issue that we should consider is how they, totally or marginally, affect the income distribution observed in the source community of the migratory flow. However, if the remittances are considered as an endogenous variable and as a potential replacement of the household incomes in the source country, the economic issue which would arise would be based on the comparison between the observed distribution of income and the one that would be obtained if migration did not occur. A study on Nicaragua (Barham \& Boucher, 1995), using both methods, suggests that, when the remittances are considered exogenous, they reduce income inequalities, whereas they contribute to the increase of income inequalities if they are considered an endogenous variable.

Similarly, the numerous studies on the relationship between migration and income inequality in the destination countries have produced conflicting results. For example, Borjas Freeman, and Katz (1992) have shown that the growth of unskilled migration may exacerbate the income gap between more educated native workers and those less educated (workers not qualified who have left school prematurely). Subsequent research has revealed, however, that this kind of analysis could be influenced by the features of the data set utilised and that the impact of immigration on the income distribution in the country of destination could depend on the assumptions made by the researcher about the socio-economic characteristics of immigrants, the structure of the production system and the public policies adopted in the field of immigration and welfare (cf. Chiswick, 1983, 1992, 1998; Davies \& Wooton, 1992). Therefore, it is not inconceivable that immigration has a negligible or no impact on income inequality (Enchautegui, 1993; Card, 2009) or that it generates an equalising effect, namely a smoothing gaps effect, especially when the levels of education and professional experience of immigrants are very high (cf. Kahanec \& Zimmermann, 2008, 2009). Recent studies (see Docquier, Özden, \& Peri, 2010) show, for example, 
DRUŠ. ISTRAŽ. ZAGREB GOD. 25 (2016), BR. 4, STR. $455-480$

VILLANI, S., FERRARA, L., LIOTTI, G.:

HOW INTERNAL... that immigration in Europe in the decade from 1990 to 2000 had a positive effect on the average wage of native workers, while the extent of wage losses determined by emigration was approximately equal to or greater than the gains generated by immigration. This phenomenon would have to convince all European governments to debate the causes and the effects of their significant emigration rates more seriously, especially those of their highly skilled professionals.

\section{A brief history of the Italian internal migration}

In terms of migration, Italy is certainly an emblematic case, although certainly not a unique example, because throughout its history it has been from time to time a country of emigration, internal migration and immigration from abroad.

Italian emigration presents some special features. First of all, it began after the beginning of the out-migratory flows from Germany and the Anglo-Saxon countries, but quickly reached such large dimensions which have made it one of the most important phenomena of human mobility at the beginning of the twentieth century. Secondly, Italian emigration had its peak between 1900 and 1914, a period of remarkable economic growth for Italy, while in other European countries, in conjunction with economic development, there was a decrease in outward migration flows.

After the unification of the country, in the last decades of the nineteenth century, there was a great wave of emigration to the overseas countries, especially to the Americas. This process began in the regions of Northern Italy and was then gradually extended to the southern regions, intensifying at the turn of the twentieth century and contributing to a greater extent to what will be called the Great Migration. This large flow gradually decreased since the 1920s, running out completely with the Second World War. This result was caused by:

- the restrictive immigration policy of the United States which established, with the Johnson Act, a restrictive and discriminatory policy towards the European countries of the Mediterranean;

- the anti-emigration policy of fascism;

- the great depression of the thirties.

In the decades following the Second World War the migratory flows outgoing from the European continent began to have new features. Moreover, new destinations (such as Australia, Venezuela and Israel) emerged alongside the traditional migratory destinations (the Americas, North and South). However, in this period, the Italians emigrated especially to France and Switzerland. 
DRUŠ. ISTRAŽ. ZAGREB GOD. 25 (2016), BR. 4 STR. $455-480$

VILLANI, S., FERRARA, L., LIOTTI, G.:

HOW INTERNAL..
In quantitative terms, taking into account both the transoceanic and the intra-mainland migratory phenomena, in Italy the emigration had a significant weight: over a century, between 1876 and 1976 (when net migration ${ }^{5}$ became positive), about 24 million Italians emigrated. ${ }^{6}$

Italy has been characterized, however, also by a large internal movement of people, which began in the fifties and sixties. In recent years Italy has stopped being an underdeveloped and largely agricultural country, becoming a state which was going to get into the select group of the most advanced industrial countries. Those were the years of the socalled "economic miracle", during which time the demographic configuration of Italy experienced a real earthquake. In the twenty years between 1950 and 1970, in fact, more than 9 million Italians moved and the consequence was a real exodus from the South to the North of Italy, from the North-East to the North-West, from the countryside to the cities.

From the mid-seventies to the late eighties the migration flows were characterized by a continuous and drastic drop, mainly due to the reduction in commuting towards the area of the so-called "industrial triangle".7 This decrease in the number of territorial displacements along the axis South-North coincided with the transformation of Italy from an emigration country to a country of (even) immigration. In fact, Italy has become in recent decades a country of immigration, an important immigration country, while at the same time it continued to be a country of emigration, an important emigration country. ${ }^{8}$

Simultaneously, but especially in the second half of the nineties, there was a resumption of local displacements from the South to the North of Italy and some scholars remembered the great migration of the Italian economic boom. However, these "new" internal migrations have different characteristics from the latter. ${ }^{9}$ Recent research ${ }^{10}$ shows that the new phase of migration which began from the mid-90s is characterised, unlike that of the $50 \mathrm{~s}$ and $70 \mathrm{~s}$, by a minor scale of the phenomenon and a greater selectivity. It involves, in fact, young generations with a higher level of education and the female component, which is increasing to half the amount of migrants. The current age structure of migrants from the South to the Centre-North of the country is concentrated in the 25-29 and 30-34 working age ranges, which in 2012 had a negative gap equal, respectively, to 18,000 and 15,000 units.

This phenomenon affects negatively the demographic evolution of the Mezzogiorno. Young people who are at a reproductive age and are equipped with a high level of expertise and professional skills are migrating to the North of the country and abroad, especially to Germany, Switzerland and 
DRUŠ. ISTRAŽ. ZAGREB GOD. 25 (2016), BR. 4, STR. $455-480$

VILLANI, S., FERRARA, L., LIOTTI, G.:

HOW INTERNAL... the United Kingdom. This implies that, during the next half century, the Mezzogiorno could lose more than a fifth of its population. Urban areas, from which economic development should start again, will be most affected by this phenomenon, which is leading to the transformation of Southern Italy into an area with a high risk of human and industrial desertification. ${ }^{11}$

\section{The Italian internal migration and the desertification process of Southern Italy}

The studies mentioned in the section Migration and inequality: A brief review of the literature clearly show that migration flows, as alleged by John Kenneth Galbraith (Galbraith, 1979), can work as an effective instrument of redistribution and could continue to play this role in the future. A conscious, and even strategic, management of these flows is possible and desirable (Castles, 2007). We argue, however, that migration in itself would not resolve the issue of inequality. At most, it would shift this forward (Piketty, 2013), because redistribution through immigration does not exempt from previously creating a basic set of rules and institutions aimed at stimulating a major coordination and collaboration by countries to change the present international management systems of migration (in order to take into consideration the interests of migrants and their source countries) and correct their redistributive effects (trying to extend to all the economic benefits produced by migration).

Therefore, the need for additional in-depth research on the economic and fiscal impact of migration and, in particular, on the effects produced by the latter on income inequalities and social mobility has become evident, especially in the long run. The present paper moves in this direction, attempting to understand, referring to the Italian case, whether and to what extent the new internal migration of population from the South to the Centre-North of the country can have an equalising effect, namely a downsizing effect of income inequalities existing within the destination regions, thereby reducing economic imbalances between the richest and poorest areas. A result which cannot be underestimated, especially in light of:

- the latest data on the size of internal migration and current demographic trends, which testify that the Mezzogiorno (the poorest areas of Southern Italy) has now become an area subject "to a high risk of human and industrial desertification" and more and more dependent on the rest of the country (cf. SVIMEZ, 2014, pp. 106-124); 
DRUŠ. ISTRAŽ. ZAGREB GOD. 25 (2016), BR. 4 STR. $455-480$

VILLANI, S., FERRARA, L., LIOTTI, G.:

HOW INTERNAL...
- the most recent economic studies on income inequality, which clearly show how it "has a negative and statistically significant impact on medium-term growth" (cf. Cingano, 2014; OECD, 2011, 2014a, 2014b, 2014c; Stiglitz, 2012);

- the policy indications that can be drawn from the most recent empirical evidence on the impact of migration on the labour market, which show how "more mobility within Europe and in particular within the euro area would improve the European-wide labour market, and that means the economy too" (cfr. Jauer, Liebig, Martin, \& Puhani, 2014).

One of the aims of the paper is also to test the hypothesis of skilled immigration equalising, formulated recently by Kahanec and Zimmermann $(2008,2009) .{ }^{12}$ We have chosen, however, to utilise single-country data at a regional level to determine the direction of the effect of immigration on income inequality, because the literature review presented in the previous paragraph clearly shows that the results of studies carried out so far depend very often on the estimation methods and the quality of the data used, on the examined sample coverage, but especially on the differences in economic, social and institutional characteristics of countries.

The paper is structured as follows: in the following section the first exploratory analysis of the variables used in the work will be developed. In particular, in this section, we will attempt to identify and study the trends that these variables have had in the time period considered. Therefore, we will describe the theoretical model developed and the results obtained through the use of a regression analysis with panel data. The paper also contains a section in which we analyze the legal framework in Italy within the European context about high and low skilled immigration, long-term immigration and resident workers.

\section{DATA DESCRIPTION}

\section{The impact of internal migration and economic crisis on regional income inequality in Italy}

Some of the most important issues which have characterized the economic debate in Italy in recent years - especially since the outset of the economic crisis - concern the trend of income inequality, unemployment and migration.

Following the theories of Galbraith (1979), Kahanec and Zimmermann $(2008,2009)$ illustrated in the previous pages, this work attempts to verify whether immigration can have positive redistributive effects on regional income inequality; in particular, it tests whether a positive Net Migration Rate 
DRUŠ. ISTRAŽ. ZAGREB GOD. 25 (2016), BR. 4, STR. $455-480$

VILLANI, S., FERRARA, L., LIOTTI, G.:

HOW INTERNAL... (hereafter, NMR) can affect negatively the value of the Gini coefficient in those regions which experience relevant immigration flows.

In this paragraph, we focus on the following three variables: the regional NMR, the regional unemployment rate and the Gini index, used to measure the degree of income inequality existing within individual regions. ${ }^{13}$ These data were extracted from the database of the Italian Institute of Statistics (ISTAT) and reprocessed by us to make the regression analysis presented hereafter.

The choice of the 2003-20114 period is not random. We intended to analyse the relationship between the abovementioned variables at the pre-crisis time - but without going too far back in time - and the changes which have been brought about in the post-crisis period.

One result of the 2007 economic crisis has been the rise in unemployment rates..$^{15}$ Analysing data on the regional unemployment rates, we can isolate two different situations regarding Italian regions: in the North, notwithstanding the severity of the financial crisis, the existence of a consolidated industrial sector has limited the increase of unemployment, whereas in the Central and Southern regions, the impact of the crisis on unemployment - especially for younger people - has been devastating. ${ }^{16}$ Figure 1 describes the trend in unemployment rates regarding the Italian regions.

Figure $1 \mathrm{a}$ and $1 \mathrm{~b}$ show that the gap in unemployment rates between Central-Northern and Southern regions has been evident since 2003, and that this gap has grown since the economic crisis hit the Italian economy in 2007. In fact, the average unemployment rate in the South is double that of the North and this phenomenon confirms that the poorest areas of the country were affected negatively by the crisis.

It is interesting to analyse the trend of the regional Gini coefficient from 2003 to 2011. In Figure 2a and 2b, we can see the Gini index trend and how - in general - income inequality tends to rise in the Southern regions of Italy (except for Sardegna and Abruzzo). Indeed, in Campania, Molise, Apulia, Basilicata and, to some extent, Sicily, the Gini coefficient in 2011 was higher than in 2007, while for Calabria its value is similar. Conversely, the situation regarding Northern Italy is quite different: in most of the Northern regions (expect for Liguria) the Gini coefficient value in 2011 is lower or similar to that of 2003.

For each region, the in-flow and out-flow migration data have been transformed, dividing them by the respective amount of population that lived in them at time $t$. This transformation allowed us to create a composite index which ranges from 0 to 1 and gave us "the regional mobility degree", that is, the trend in the entry and exit rates of people for each examined region. 


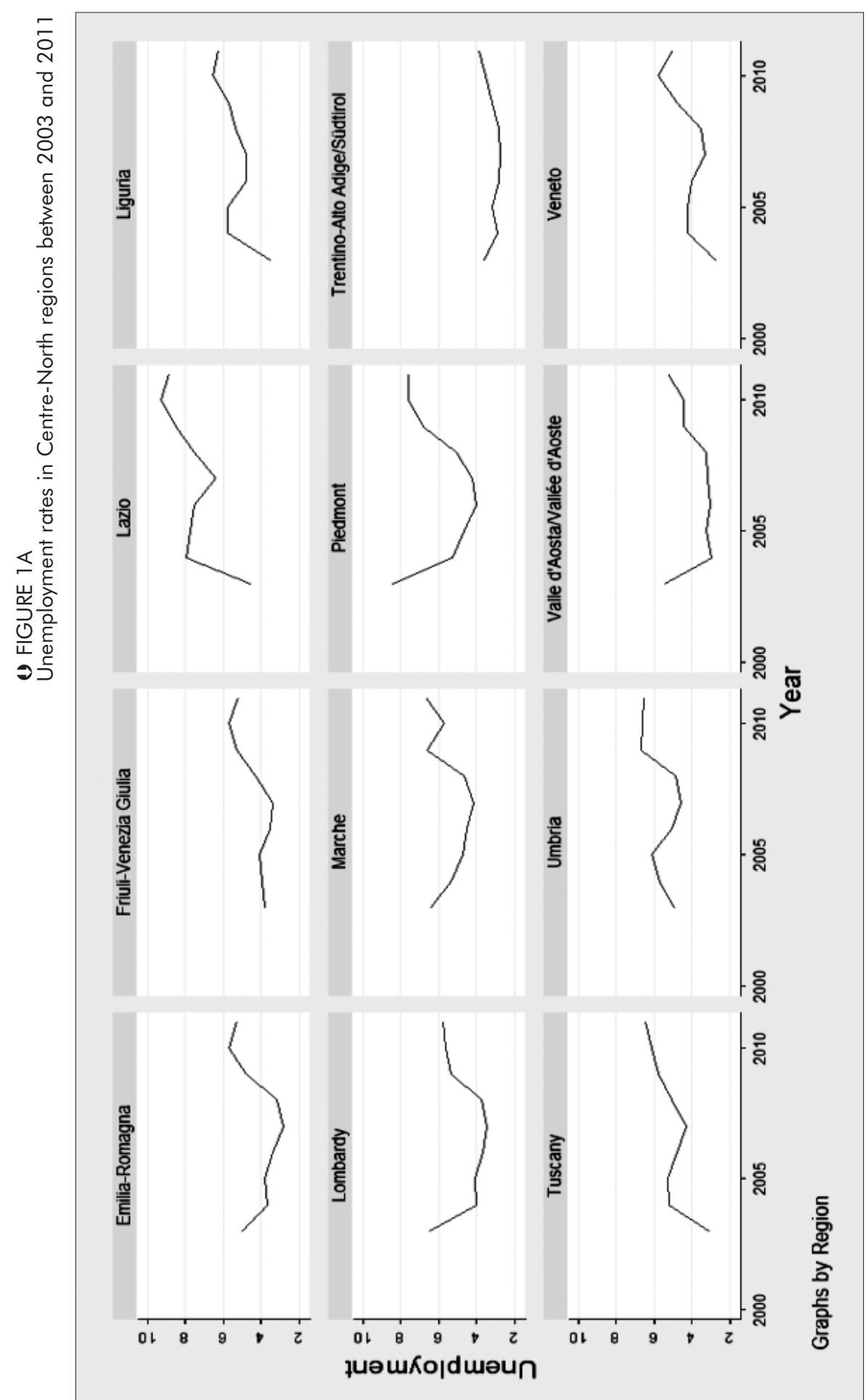









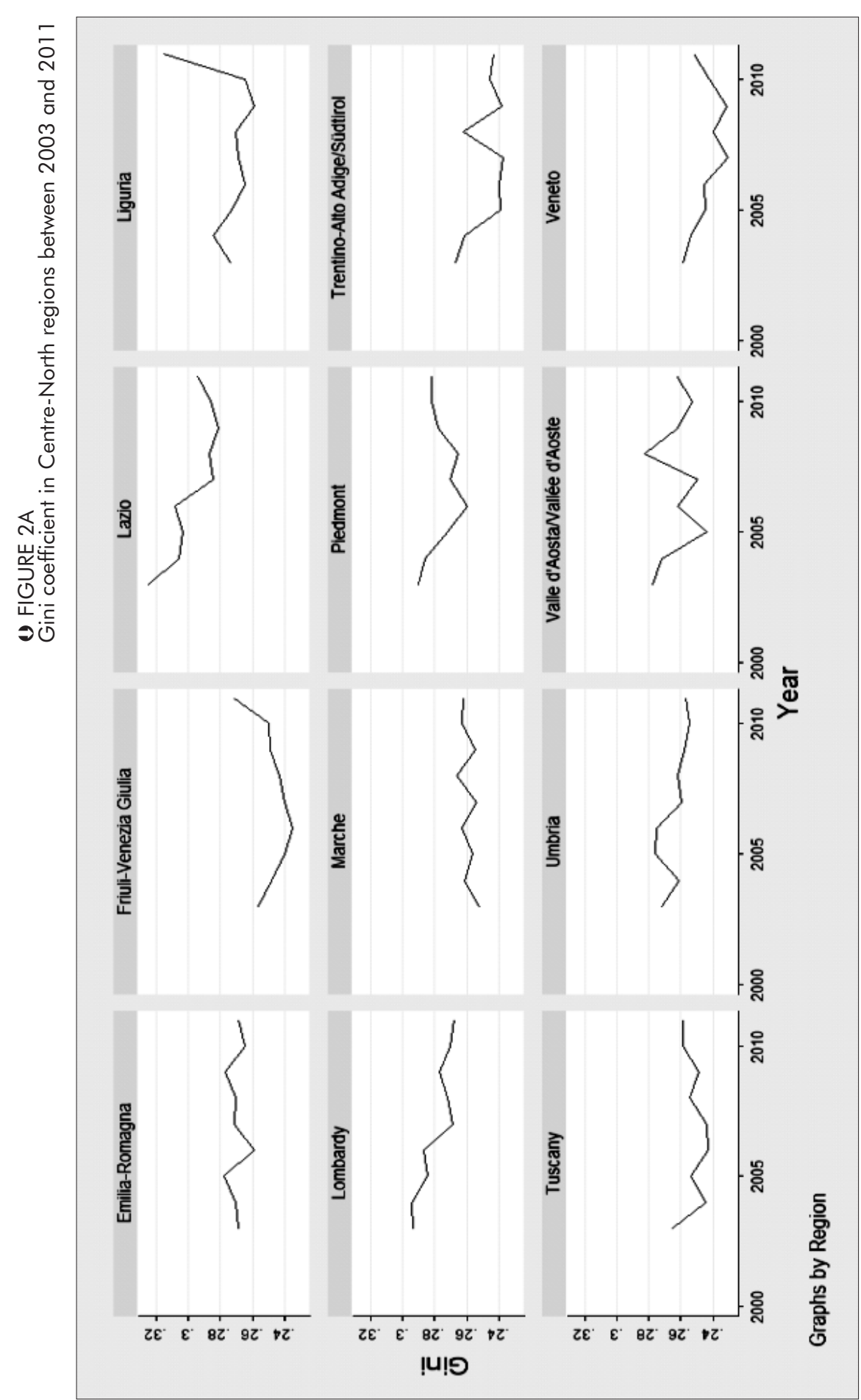




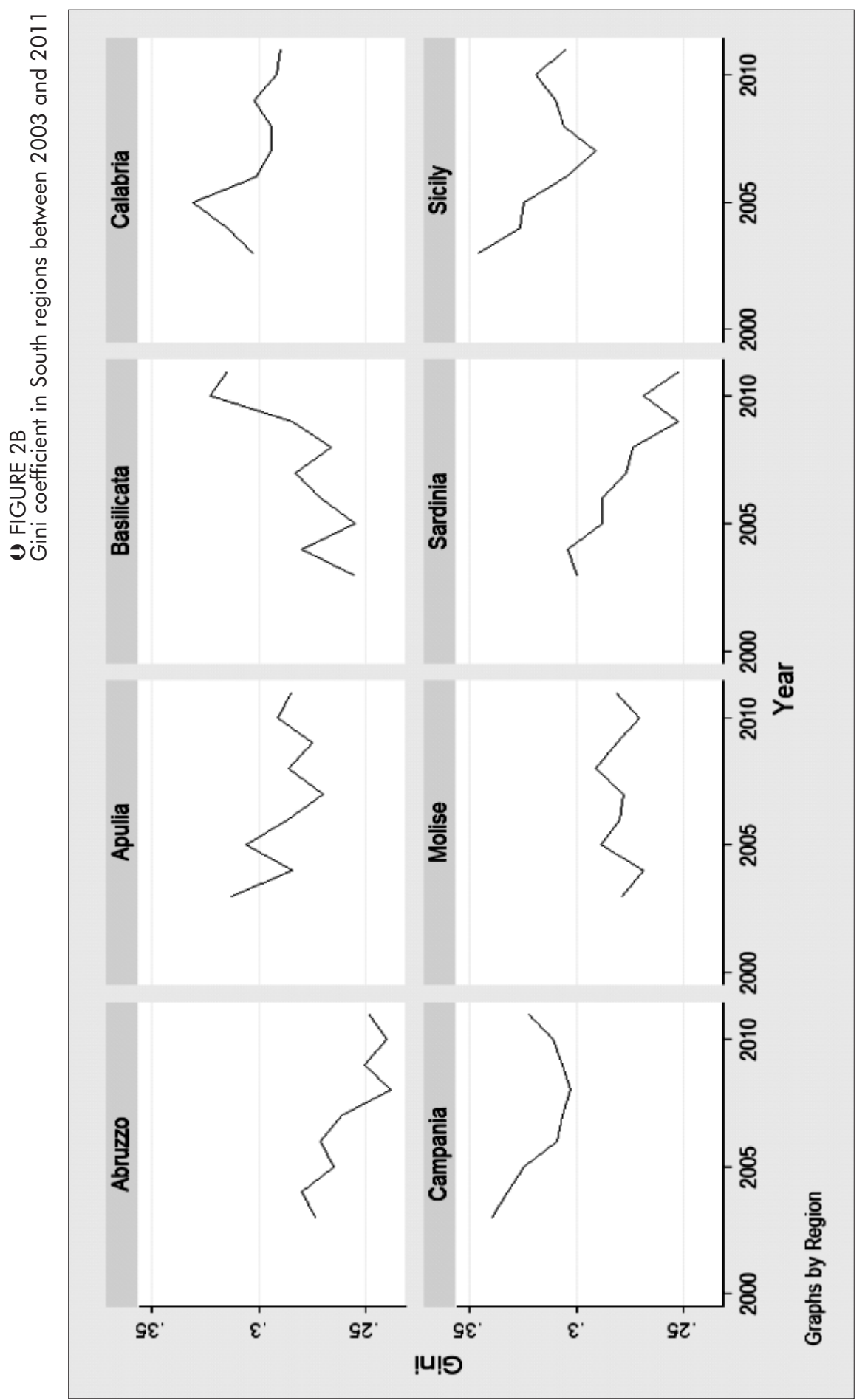

Source: Eurostat database on monetary poverty and income inequality, http://ec.europa.eu/eurostat 
DRUŠ. ISTRAŽ. ZAGREB GOD. 25 (2016), BR. 4 STR. $455-480$

VILLANI, S., FERRARA, L., LIOTTI, G.:

HOW INTERNAL..
Therefore, the Net Migration Rate enables us to study the temporal dynamics of migration flows among the Italian regions. Population displacement between the South and the Centre-North of the country has been, in the past and even today, considered a very important social phenomenon in the history of contemporary Italy. Recent research has shown how these population displacements combined with a low fertility have enhanced the formation of human capital, facilitating family strategies of upward social mobility, the construction of a more balanced labor market, increases in income and a decline in the graying of the population. ${ }^{17}$

The Net Migration Rate was calculated as the difference between the number of people entering and leaving a specific region, divided by the average value of population in year $i$ (see below equation 1 ):

$$
N M R_{i, t}=\frac{100\left(\operatorname{Inf}_{i, t}-\mathrm{Out}_{i, t}\right)}{\text { Pop }_{i, t}}
$$

where NMR is the Net Migration Rate, Inf and Out represent the number of people entering and leaving the specific region $i, t$ is the time period considered in our analysis, and Pop is the population of the region considered. We multiply by 100 to have the value in percentage terms.

The sign of the Net Migration Rate can be positive, negative or null, depending upon whether in the region $i$ the number of immigrants is, respectively, higher, lower or equal to the number of emigrants.

Our analysis focused on the study of the relationship between the change (percentage variation) in the regional Gini coefficient and the cumulative regional Net Migration Rate in the period mentioned above (2003-2011). The two variables are built in the following way:

1) the percentage variation (CH_GINI) in the Gini coefficient is calculated as

$$
\text { CH_GINI } I_{i}=\sum_{2003}^{2011}\left(\text { Gini }_{t+1 i}-\text { Gini }_{t, i}\right)
$$

2) the Cumulative Net Migration Rate (CNMR) is represented by the sum of the annual Net Migration Rate for each region between 2003 and 2011:

$$
C N M R_{i}=\sum_{\mathrm{t}-2003}^{2011} M B_{i, t}
$$

In Figure 3 we show the relationship between cumulative changes in Gini coefficient and Net Migration Rate from 2006 (the year previous to the beginning of the crisis) to 2011. 
DRUŠ. ISTRAŽ. ZAGREB GOD. 25 (2016), BR. 4, STR. $455-480$

VILLANI, S., FERRARA, L., LIOTTI, G.:

HOW INTERNAL...

(1) FIGURE 3

Changes in the Gini coefficient and the CNMR between 2006 and 2011
As it is possible to note, their relationship is negative and this means that when the Net Migration Rate is positive (that is in the specific region $i$ the number of immigrants is greater than emigrants), the regional income inequality tends to decrease, or better, the Gini index declines.

This relationship seems to be systematic for almost all Northern regions, except for Liguria. For Southern ones, a positive relationship between the Net Migration Rate and the regional income inequality is detected for Basilicata, Campania and Molise (although for this last region the value of the increase in the Gini coefficient is very high), conversely, for Puglia, Calabria and Sicilia it is not consistent. It is very likely that for these three regions of Southern Italy, there are other factors which have affected the variation in the Gini coefficient. For example, it is possible that the economic crisis has produced a reduction in the income for both the upper and the middle classes. This situation could be determined by a reduction in the Gini coefficient within a generalised situation of poverty.

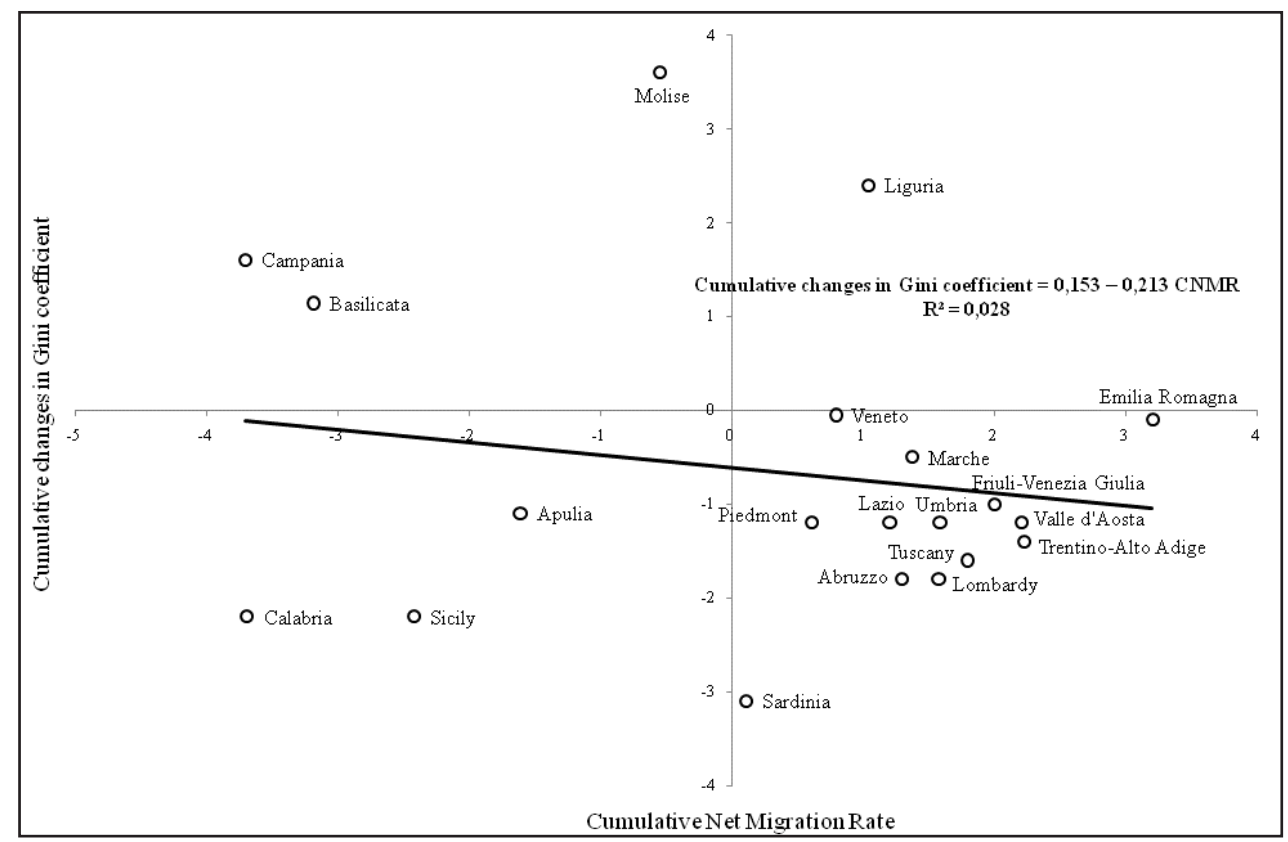

\section{Methodology and econometric results}

In our econometric analysis we used a panel data approach because it is very easy to suppose that among Italian regions there is heterogeneity and therefore we estimated two different models: the first takes into consideration the error term as correlated to the regressors (equation 4) and the second assumes that the former element is not correlated to the latter ones (equation 5). 
DRUŠ. ISTRAŽ. ZAGREB GOD. 25 (2016), BR. 4 STR. $455-480$

VILLANI, S., FERRARA, L., LIOTTI, G.:

HOW INTERNAL..

2 TABLE

Impact of NMR and Unemployment on regional Gini coefficient
Fixed effect model:

$$
\text { Gini }_{i, t}=\alpha_{i}+\beta U n_{i, t-1}+\delta N M R_{i, t-1}+u_{i, t}
$$

Random effect model:

$$
\operatorname{Gini}_{i, t}=\alpha_{i}+\beta U n_{i, t-1}+\delta N M R_{i, t-1}+u_{i, t}+\varepsilon_{i}
$$

In both equations we introduced a lag, as we hypothesised that the unemployment rate and Net Migration Rate at time $t-1$ affect the Gini coefficient at $t$ time. Moreover, the introduction of a lag for each of the explained variables allows us to overcome the causality problem. After which, since the Hausman test allowed us to reject the hypothesis of correlation between the error term and the regressors, we estimated the equation (5) and used the Wooldridge test to rule out the serial correlation in the residuals. Therefore, having detected the presence of cross-sectional dependency using the Pesaran CD test, we selected the Driscoll and Kraay option to obtain heteroscedasticity- and autocorrelation-consistent standard errors, to rule out any form of spatial and temporal dependence. Subsequently, we estimated equation (4), first, on the entire period observed and, then, on both two sub-periods in which it was broken down. Finally, utilising the VIF test, we made sure that there was no multicollinearity.

Table 1 shows the results of our estimates. They reveal that the relationship between Net Migration Rate and income inequality is negative. This means that a positive Net Migration Rate (number of immigrants greater than emigrants) seems to cause a reduction of the regional Gini coefficient. The result does not change regardless of the period we consider. The above mentioned relationship is always negative and significant. The Net Migration Rate is higher in the postcrisis period, and the $R^{2}$ are very high for the whole period and for both sub-periods in which the former was broken down.

\begin{tabular}{llll}
\hline Independent variable & Period & & \\
\cline { 2 - 4 } & $2003-2011$ & $2003-2007$ & $2008-2011$ \\
\hline Unemployment & $\begin{array}{l}0.323^{* * *} \\
(0.031)\end{array}$ & $\begin{array}{l}0.344^{* * *} \\
(0.027)\end{array}$ & $\begin{array}{l}0.231^{* * *} \\
(0.018)\end{array}$ \\
Net Migration Rate & $-1.861^{* *}$ & $-1.142^{* * *}$ & $-3.904^{* * *}$ \\
& $(0.749)$ & $(0.375)$ & $(0.999)$ \\
Constant & $24.975^{* * *}$ & $24.888^{* * *}$ & $25.612^{* * *}$ \\
& $(0.275)$ & $(0.368)$ & $(0.186)$ \\
R-squared & 0.5068 & 0.5266 & 0.4893 \\
Discr/Kraay & YES & YES & YES \\
Observation & 160 & 80 & 80 \\
\end{tabular}

Dependent variable: Gini coefficient 
At this point, we utilised regional unemployment rates as a control variable. We noted that - as expected - a rise in the unemployment rate increases the regional Gini index and, therefore, the degree of regional income inequality.

\section{INTERNAL MIGRATIONS AND IMMIGRANT WORKERS IN ITALY. JURIDICAL TOPICS ABOUT THE "EQUALIZING EFFECT" OF IMMIGRATION}

Between the various variables that influence the impact of the NMR on regional income inequality, we should start underlining that in the NMR both nationals and foreigners are included (OECD, 2014, p. 90):18 so, the composition of migration flows between Italian regions is influenced by the legal frameworks on the freedom of movement of EU-citizens and third-country nationals. The juridical perspective, besides, will show that high-skilled migration is related to the legal limits to accessing regional welfare benefits (education, professional training, employment services and programs). The enhancement of our study will have to consider the full implementation of the $E$ ropean Agenda on migration (COM (2015) 240), which promotes legal high-skilled migration as a development factor.

One preliminary question concerns the function of intra-European free movement of workers as a model for EU migration law.

In the Ruiz Zambrano case in 2011, the ECJ recognized that EU Treaties suggested an alternative legal framework on third-country nationals instead of EU citizenship, the Area of Freedom, Security and Justice, that could deviate from the common constitutional traditions on the freedom of movement of citizens (Thym, 2013).

Analyzing Italian Constitutional Court case law, it is possible to find in EU migration law a positive constitutional base in virtue of Common Constitutional Traditions in Article 6 TEU (Ronchetti, 2012; Grosso, 2010; Fracchia, 2013), from which we could identify common constitutional rights and duties for individuals, an "administrative" citizenship for third-country nationals.

According to the constitutional reform in 2001, if the State has the legislative power on the criteria for the attribution of national citizenship, Regions are responsible for a large part of social rights and the active participation of foreign residents in the life of the local communities. Particularly qualifying for this sort of "regional citizenship" is the sector of immigrant integration, which involves all social competencies of the Regions in the access of foreigners (that are "vital parts of the community", C. Court no. 222/2013) to welfares, and influences the intra-regional migration flows and NMR (Biondi Dal Monte, 2013; Calafà, 2012). 


\section{CONCLUDING REMARKS}

The econometric analysis presented in this paper shows how the new internal migration of the resident population from the South to the Centre and the North of Italy has a substantially equalising effect, since it seems to cause a reduction of income inequality within destination regions, the richest, and helps to increase the latter in the poorest source regions. This result most likely depends on the characteristics which distinguish this new wave of migration towards Central and Northern Italy. ${ }^{19}$ In addition to the changes in the areas of departure and destination flows, in fact, the most important factor of discontinuity, typically related to this "new" internal migration, "seems to concern the degree of education of immigrants".20 The models utilised to study the characteristics of internal migrants and their changes over time confirm, in fact, "that Southerners who have decided to emigrate are on average more educated than the ones left in the Mezzogiorno". It seems, in other words, that college graduates and high school graduates have a greater propensity to emigrate compared to those who did not obtain a diploma higher than middle school and that, therefore, there has been a process of "positive selection" of emigrants based on their educational level, very similar to that which is generally found in contemporary international migration (Chiswick, 2000). This distinctive feature of the new movements of the resident population among the Italian regions was reported by most recent studies of demography and sociology (Cardinale, 2012; Panichella, 2009, 2012, 2013) and is confirmed by the surveys done by ISTAT and SVIMEZ. ${ }^{21}$ Some studies have shown, however, that skilled emigration is not a novel character of the new migration, but a structural character which has qualified the whole history of migration from the South to the Center and the North of Italy.22 These studies contain extensive empirical evidence which proves how the propensity to emigrate of the most educated individuals is always the same, while the propensity of the less educated individuals and the less economically endowed to emigrate has changed. The alleged discontinuity with the past is connected, rather, to another aspect typically related to these new migrations. Currently, there are not enough data to prove it, but probably the average level of education of the Southerners emigrating to the Center-North is higher than the one of the residents of the destination zones. In the past, however, the average level of education of the Southerners who emigrated to the Center-North was lower than that of the people who welcomed them and this affected negatively not only the financial situation of local governments in Northern Italy but also the welfare of residents of the destination areas of migratory flows. ${ }^{23}$ 
DRUŠ. ISTRAŽ. ZAGREB GOD. 25 (2016), BR. 4, STR. $455-480$

VILLANI, S., FERRARA, L., LIOTTI, G.:

HOW INTERNAL...

\section{? TABLE 2}

Level and variation of income inequality in the major Italian territorial divisions between 2008 and 2012
Our results depend very plausibly on this element of discontinuity that characterizes the new migrations in comparison to those of the past, a hypothesis which would find a solid foundation in the Kahanec and Zimmermann model mentioned above and which, in turn, allows us to go back to the causes of the higher level and the broader increase in income inequality in the Mezzogiorno, compared to the rest of the country (cf. Table 2).

\begin{tabular}{lrrrrr}
\hline & \multicolumn{2}{c}{ Gini index } & & \multicolumn{2}{c}{ Income inter-decile ratios } \\
\cline { 2 - 3 } \cline { 5 - 6 } Territorial divisions & 2008 & 2012 & & 2008 & 2012 \\
\hline Mezzogiorno & 32,4 & 33,2 & & 4,2 & 4,8 \\
Center-North & 30,2 & 30,7 & 3,7 & 3,8 \\
Italy & 31,8 & 32,4 & 4,1 & 4,2 \\
Among areas & 6,9 & 7,1 & - & - \\
Within the areas & 18 & 18,4 & - & - \\
Overlap & 6,9 & 7 & - & - \\
\hline
\end{tabular}

Source: SVIMEZ on data ISTAT, IT-SILC 2012

If we assume, in fact, that the Southerners who have decided to move to the Centre-North are not a representative sample of the Southern society, but only the most educated and equipped with skills, resources and motivations, it is highly likely that they will be also, on average, more educated and wealthier than the people that welcome them, or at least they will have a level of education and wealth that allows them to contribute more to the improvement of the economic performance - and therefore of the wealth - of the Central and Northern regions. At the present time we cannot be sure that our conjecture is true, because we do not have enough data to prove it. Therefore, we merely point out that such a phenomenon cannot and should not be underestimated, because it can lead to an automatic increase of economic imbalances existing within the country. Furthermore, recent studies have shown that the migration of human capital can have a negative effect on the welfare and the economic growth of countries. ${ }^{24}$ Underestimating this phenomenon means running the risk of consolidating and accelerating the aforementioned process of human and industrial desertification of the Mezzogiorno, as well as its degree of economic underdevelopment and dependence on the rest of the country.

In this framework, we can observe all contradictions of the immigration law in Italy.

As reported in a 2013 EMN study, "Based on Istat (National Institute of Statistics) data and according to all migration experts, the integration of migrant workers in the Italian labour market generally follows a "subordinate integration" model, in which the totality (or at least the majority) of foreign- 
DRUŠ. ISTRAŽ. ZAGREB GOD. 25 (2016), BR. 4 STR. $455-480$

VILLANI, S., FERRARA, L., LIOTTI, G.:

HOW INTERNAL... ers have low-level jobs that Italians are no longer willing to accept (...) In this time of severe internal economic and occupational problems there seems not to be a particular concern about brain drain caused to countries of origin".

The Legislative Decree no. 108/2012 introduced a new residence permit called "EU Blue Card", issued for two years (in case of an open-ended contract), or for the duration of the employment (in any other case). In order to fully implement the regulations and establish procedures for the recognition of professional qualifications obtained abroad and not regulated in Italy, the Ministry of Interior, in collaboration with the Ministry of Foreign Affairs and the Ministry of Education, University and Research, has drawn up a specific procedure allowing the rapid recognition of qualifications.

The length limits of this paper prevents reporting and analysing the references to Blue cards and other instruments for strengthening legal high-skilled immigration in the regional Operative programs of ERDF and ESF in Mezzogiorno. But, we think that defining the contents of "administrative citizenship" of legal immigration in regional welfare and qualifying the role of non-resident EU workers in the economies of northern Italy are important topics for the future political agenda in Italy.

\section{APPENDIX}

\section{CNMR and Changes in Gini coefficient (Ch_Gini)}

$\begin{array}{lrr}\text { Region } & \text { CNMR 2004-2012 } & \text { Ch_Gini 2004-2012 } \\ \text { AB } & 1.28 & -1.8 \\ \text { BAS } & -2.94 & 1.14 \\ \text { CAL } & -3.34 & -2.2 \\ \text { CAM } & -3.32 & 1.6 \\ \text { EM-RO } & 3.03 & -0.1 \\ \text { FVG } & 1.84 & -1 \\ \text { LAZ } & 1.09 & -1.2 \\ \text { LIG } & 1.03 & 2.4 \\ \text { LOM } & 1.42 & -1.8 \\ \text { MAR } & 1.44 & -0.5 \\ \text { MOL } & -0.55 & 3.6 \\ \text { PIE } & 0.55 & -1.2 \\ \text { PUG } & -1.69 & -1.1 \\ \text { SARD } & -0.19 & -3.1 \\ \text { SIC } & -1.55 & -2.2 \\ \text { TOSC } & 1.66 & -1.6 \\ \text { TRENT } & 1.93 & -1.4 \\ \text { UM } & 1.62 & -1.2 \\ \text { VAL.OA } & 1.86 & -1.2 \\ \text { VEN } & 0.79 & -0.5\end{array}$


${ }^{1}$ For a broad review of these studies and the frontier issues related to the so-called Immigration Economics, see Bodvarsson and Van den Berg (2009, 2013), Constant and Zimmermann (Eds., 2013) and Borjas (2014).

2 A review of the economic studies on the multidimensional nature of inequality and poverty is part of a recent research by the bank of Italy by Rolf Aaberge and Andrea Brandolini (Aaberge \& Brandolini, 2014). For a broad study on the socio-cultural aspects of various kinds of inequality, see Therborn (2013).

3 A collection of case studies on particular kinds of relationships which can be found between migratory phenomena and inequalities can be found in the World Development Report written by Black, Natali, and Skinner (Black, Natali, \& Skinner, 2006).

${ }^{4}$ Regarding this, other forms of inequalities could also be considered as determinants for this phenomenon. For example, the effect produced by the so-called "inequality of opportunities" cannot be underrated, as noted by Stiglitz (1969) in his well-known work on rural-urban migration, labour supply and the wage gaps between the rural and urban sectors.

5 That is the difference (in absolute values) between the number of people entering and leaving a specific territorial circumscription.

${ }^{6}$ Cf. Federici (1979), Bonifazi and Heins (1996), Pugliese (2007), Bonifazi et al. (2009), and Cesareo (2015).

7 The term "industrial triangle" indicates a heavily industrialized and active area of the North-West of Italy, corresponding to a triangle whose vertices are identified in the cities of Turin, Milan and Genoa.

8 See again Pugliese (2007), Bonifazi, Heins, Strozza, and Vitiello (2009), and Cesareo (2015).

${ }_{9}$ Cf. Panichella (2014) and SVIMEZ (2014).

10 See for all SVIMEZ (2014), pp. 106-124.

11 See again SVIMEZ (2014), pp. 106-124 and 557-651.

12 The analysis conducted by these two economists suggests that immigration of skilled workers shows a great potential in reducing inequalities in destination countries of migration flows. A channel through which this effect would be realized is the increase in the relative wage of unskilled workers compared to that of skilled workers. The immigration of unskilled workers would produce, however, an increase in inequality and, only in exceptional circumstances, curtailments.

13 In accordance with the conventions adopted within the European Union, the Gini index has been calculated by assigning to each person the equivalent income of the household to which they belong and considering the individuals as statistical units. The net household income is equal to the sum of incomes from employed and self-employed labour, those from real and financial capital, pensions and other public and private transfers, excluding personal taxes, the $\mathrm{Mu}$ nicipal Property Tax named ICI (Imposta Comunale sugli Immobili) and the social contributions of employed and self-employed work- 
DRUŠ. ISTRAŽ. ZAGREB GOD. 25 (2016), BR. 4, STR. $455-480$

VILLANI, S., FERRARA, L., LIOTTI, G.:

HOW INTERNAL... ers. This calculated amount does also not include transfers paid to other families (for example, the financial provision for spousal support after separation or divorce).

14 It is useful to inform the reader that the regional NMRs for the year 2011 are calculated until the date of 9th October, because the estimates realized in this article take into account the series of resident population registered in the intercensal decade 2001-2011 conducted before the release of the 15th General Census of Population and Housing. Our choice is determined by the need for homogeneous data although tainted by the coverage error of the municipal population registers signaled by ISTAT.

15 Unemployed people include people aged 15-64 who were (all three conditions must be fulfilled simultaneously): 1) without work during the reference week; 2 ) available for work at the time (i.e. were available for paid employment or self-employment before the end of the two weeks following the reference week); 3) actively seeking work (i.e. had taken specific steps in the four-week period ending with the reference week to seek paid employment or self-employment), or who found a job which started within a three month period.

16 See D'Isanto, Liotti, Musella (2014).

17 See for all Dalla Zuanna (2006), Impicciatore and Dalla Zuanna (2006).

18 OECD (2014), Society at a Glance 2014: OECD Social Indicators, OECD Publishing.

19 On the history of migration and the immigration policies in Italy, see Casacchia and Strozza (2001).

20 Panichella (2014), pp. 75-112.

21 Cf. ISTAT (2011), SVIMEZ (2014), pp. 106-124.

22 As argued in the past by Pica (1972) and, more recently, by Panichella $(2012,2014)$.

23 Cf. Pica (1972).

24 In this sense, cf. Lo Cicero (2010), at page 568 and the following pages.

\section{REFERENCES}

Aaberge, R., \& Brandolini, A. (2014). Multidimensional poverty and inequality, Temi di discussion, Working paper No. 976, September.

Barham, B., \& Boucher, S. (1995). Migration, remittances, and inequality: Estimating the net effects of migration on income distribution. Journal of Development Economics, 55(2), 307-331. https://doi.org/10. 1016/S0304-3878(98)90038-4

Biondi Dal Monte, F. (2013). Dai diritti sociali alla cittadinanza. La condizione giuridica dello straniero tra ordinamento italiano e prospettive sovranazionali (From social rights to citizenship. The legal status of foreigners between the Italian law and supranational perspectives). Torino: Giappichelli.

Black, R., Natali, C., \& Skinner, J. (2006). Migration and inequality. Washington, DC: World Bank. 
DRUŠ. ISTRAŽ. ZAGREB GOD. 25 (2016), BR. 4, STR. $455-480$

VILLANI, S., FERRARA, L., LIOTTI, G.:

HOW INTERNAL...
Bodvarsson, O. B., \& Van den Berg, H. (2009). The economics of immigration: Theory and policy. First Edition. New York and Heidelberg: Springer.

Bodvarsson, O. B., \& Van den Berg, H. (2013). The economics of immigration: Theory and policy. Second Edition. New York and Heidelberg: Springer. https://doi.org/10.1007/978-1-4614-2116-0

Bonifazi, C., \& Heins, F. (1996). Le migrazioni di ritorno nel sistema migratorio italiano: un riesame (Return migration in the Italian migratory system: A review). Studi Emigrazione, 33(122), 273-302.

Bonifazi, C., Heins, F., Strozza, S., \& Vitiello, M. (2009). The Italian transition from emigration to immigration country, IRPPS Working Papers, CNR, Istituto di Ricerche sulla Popolazione e le Politiche Sociali (IRPPS), Roma.

Borjas, G. J., Freeman, R., \& Katz, L. (1992). On the labor market effects of immigration and trade. In G. J. Borjas, \& R. Freeman (Eds.), Immigration and the work force: Economic consequences for the United States and source countries (pp. 213-244). Chicago: University of Chicago Press.

Borjas, G. J. (2014). Immigration economics. Princeton, NJ, USA: Princeton University Press. https://doi.org/10.4159/harvard.9780674369900

Brettell, C. B., \& Hollifield, J. F. (Eds.) (2000). Migration theory: Talking across disciplines. New York: Routledge.

Calafa, L. (2012). Migrazione economica e contratto di lavoro degli stranieri (Economic migration and the employment contract of foreigners). Bologna: Il Mulino.

Card, D. (2009). Immigration and inequality. American Economic Review, 99(2), 1-21. https://doi.org/10.1257/aer.99.2.1

Cardinale, S. (2012). Il brain-drain sud-nord in Italia dal 1990 ad oggi (The brain-drain from south to north in Italy from 1990 to present). Eunomia, 1(2), 171-191.

Casacchia, O., \& Strozza, S. (2001). Le migrazioni interne e internazionali in Italia dall'unità ad oggi: un quadro complessivo (Internal and international migration in Italy from the unification to the present system: An overview). In L. Di Comite, \& A. Paterno (Eds.), Quelli di fuori. Dall'emigrazione all'immigrazione: il caso italiano (Outsiders. From emigration to immigration: The Italian case), (pp. 50-88). Milano: Franco Angeli.

Castles, S. (2007). Can migration be an instrument for reducing inequality? International Metropolis Conference, Melbourne, 8-12 October.

Cesareo, V. (2015). La sfida delle migrazioni (The challenge of migration). Milano: Vita e Pensiero.

Chiswick, B. R. (1983). An analysis of the earnings and employment of Asian-American men. Journal of Labor Economics, 1(2), 197-214. https://doi.org/10.1086/298010

Chiswick, B. R. (1992). Jewish immigrant wages in America in 1909: An analysis of the Dillingham Commission data. Explorations in Economic History, 29(3), 274-289. https://doi.org/10.1016/0014-4983(92) 90039-Y 
DRUŠ. ISTRAŽ. ZAGREB GOD. 25 (2016), BR. 4 STR. $455-480$

VILLANI, S., FERRARA, L., LIOTTI, G.:

HOW INTERNAL...
Chiswick, B. R. (1998). Hebrew language usage: Determinants and effects on earnings among immigrants in Israel. Journal of Population Economics, 11(2), 253-271. https://doi.org/10.1007/s001480050068

Chiswick, B. R. (2000). Are immigrants favorably self-selected? In C. B. Brettell, \& J. F. Hollifield (Eds.), Migration theory: Talking across disciplines (pp. 61-77). New York: Routledge.

Cingano, F. (2014). Trends in income inequality and its impact on economic growth, OECD SEM Working Paper No. 163, OECD Publishing, Paris.

Constant, A. F., \& Zimmermann, K. F. (Eds.) (2013). International handbook on the economics of migration. Cheltenham, UK/Northampton, MA, USA: Edward Elgar.

Dalla Zuanna, G. (2006). Population replacement, social mobility and development in Italy in the twentieth century. Journal of Modern Italian Studies, 11(2), 188-208. https://doi.org/10.1080/13545710600658560

Davies, J. B., \& Wooton, I. (1992). Income inequality and international migration. The Economic Journal, 102(413), 789-802.

D'Isanto, F., Liotti, G., \& Musella, M. (2014). La mobilità giovanile nell'immobilità strutturale (Youth mobility in the structural stillness). Rivista Economica del Mezzogiorno, 4, 794-816.

Docquier, F., Özden, Ç., \& Peri, G. (2010). The wage effects of immigration and emigration, NBER Working Paper No. 16646, December.

Enchautegui, M. E. (1993). The effects of immigration on the wages and employment of black males. Washington: The Urban Institute.

Federici, N. (1979). Istituzioni di demografia (Demography institutions). Roma: Elia.

Fracchia, F. (2013). Integrazione, uguaglianza, solidarietà (Integration, equality, solidarity). Nuove Autonomie, 2-3, 229-240.

Galbraith, J. K. (1979). The nature of mass poverty. Cambridge: Harvard University Press. https://doi.org/10.4159/harvard.9780674333109

Grosso, E. (2010). I doveri costituzionali (The constitutional duties). In Lo statuto costituzionale del non cittadino (The constitutional status of noncitizens), (pp. 229-281). Milano: Giuffrè.

Harris, J., \& Todaro, M. P. (1970). Migration, unemployment \& development: A two-sector analysis. American Economic Review, 60(1), 126-412.

Impicciatore, R., \& Dalla Zuanna, G. (2006). A difficult social mobility: The education of children of Southern parents emigrated to Central and North Italy. Genus, 62(3/4), 155-201.

ISTAT (2011). Indagine 2009 sull'inserimento professionale dei dottori di ricerca. Mobilità interna e verso l'estero dei dottori di ricerca (The 2009 Survey on the professional integration of PhD graduates. Internal and abroad mobility of the PhD graduates), December.

Jauer, J., Liebig, T., Martin, J. P., \& Puhani, P. (2014). Migration as an adjustment mechanism in the crisis? A comparison of Europe and the United States, OECD Social, Employment and Migration Working Paper No. 155, OECD Publishing, Paris.

Johnson, G. E. (1971). The structure of rural-urban migration models. Eastern Africa Economic Review, June, 21-28. 
DRUŠ. ISTRAŽ. ZAGREB GOD. 25 (2016), BR. 4, STR. $455-480$

VILLANI, S., FERRARA, L., LIOTTI, G.:

HOW INTERNAL...
Kahanec, M., \& Zimmermann, K. F. (2008). International migration, ethnicity and economic inequality, Discussion Paper IZA DP No. 3450, April.

Kahanec, M., \& Zimmermann, K. F. (2009), International migration, ethnicity and economic inequality. In W. Salverda, B. Nolan, \& T. M. Smeeding (Eds.), Oxford handbook on economic inequality (pp. 455-490). Oxford: Oxford University Press.

Lipton, M. (1980). Migration from rural areas of poor countries: The impact on rural productivity and income distribution. World Development, 8(1), 1-24. https://doi.org/10.1016/0305-750X(80)90047-9

Lo Cicero, M. (2010). Il Rapporto Svimez 2010 sull'economia del Mezzogiorno, cronache meridionali del ventunesimo secolo (The 2010 SVIMEZ Report on the economy of Southern Italy, Southern Chronicles of the twenty-first century). In Economia Italiana, Unicredit, 2.

OECD (2011). Divided we stand: Why inequality keeps rising, OECD Publishing, Paris.

OECD (2014a). Rising inequality: Youth and poor fall further behind income inequality update, OECD Publishing, Paris, June.

OECD (2014b). Focus on top incomes and taxation in OECD countries: Was the crisis a game changer?, OECD Publishing, Paris.

OECD (2014c). Focus on inequality and growth, OECD Publishing, Paris, December.

Panichella, N. (2009). La mobilità territoriale dei laureati italiani: vincoli, strategie e opportunità (The territorial mobility of Italian graduates: Constraints, strategies and opportunities). Polis, 23(2), 221-246.

Panichella, N. (2012). Le migrazioni interne nel secolo scorso: vecchie e nuove migrazioni a confronto (Internal migration in the last century: Old and new migrations compared). Stato e mercato, 95(2), 255-281.

Panichella, N. (2013). Migration strategies and occupational outcomes of southern Italian graduates. Journal of Modern Italian Studies, 18(1), 72-89. https://doi.org/10.1080/1354571X.2013.730274

Panichella, N. (2014). Meridionali al Nord. Migrazioni interne e società italiana dal dopoguerra ad oggi (Southern Italy's natives who migrate to the North. Internal migration and Italian society since the postwar period to present). Bologna: Il Mulino.

Pica, F. (1972). Problemi di equità e di benessere nella finanza locale (Fairness and welfare problems in local finance). Rassegna Economica, 5, 1315-1335.

Piketty, T. (2013). Le capital au XXIe siècle (Capital in the Twenty-First Century). Paris: Edition du Seuil.

Pugliese, E. (2007). L'Italia tra migrazioni internazionali e migrazioni interne (Italy between international migration and internal migration). Bologna: Il Mulino.

Ronchetti, L. (2012). I diritti di cittadinanza dei migrant. Il ruolo delle Regioni (The citizenship right of migrants. The role of the Regions). Milano: Giuffrè.

Stark, O., Taylor, J. E., \& Yitzhaki, S. (1986). Remittances and inequality. The Economic Journal, 96(383), 722-740. https://doi.org/10.2307/2232987 
DRUŠ. ISTRAŽ. ZAGREB GOD. 25 (2016), BR. 4 STR. $455-480$

VILLANI, S., FERRARA, L., LIOTTI, G.:

HOW INTERNAL..
Stiglitz, J. E. (1969). Rural-urban migration, surplus labour, and the relationship between urban and rural wages. East African Economic Review, 1(2), 1-27.

Stiglitz, J. E. (2012). The price of inequality. How today's divided society endangers our futures. New York: W. W. Norton.

SVIMEZ (2014). Rapporto sull'economia del Mezzogiorno (Report on the economy of Southern Italy). Bologna: Il Mulino.

Taylor, J. E. (1992). Remittances and inequality reconsidered: Direct, indirect and intertemporal effects. Journal of Policy Modelling, 14(2), 187-208. https://doi.org/10.1016/0161-8938(92)90008-Z

Therborn, G. (2013). The killing fields of inequality. Cambridge, UK: Polity Press.

Thym, D. (2013). EU migration policy and its constitutional rationale: A cosmopolitan outlook. Common Marker Law Review, 50(3), 709-736.

Todaro, M. P. (1968). An analysis of industrialization employment and unemployment in less developed countries, Yale Economic Essays.

Todaro, M. P. (1969). A model of labor migration and urban unemployment in less developed countries. American Economic Review, 59(1), 138-148.

Todaro, M. P. (1971). Education and rural-urban migration: Theoretical constructs and empirical evidence from Kenya, Conference on Urban Unemployment in Africa, University of Sussex.

\section{Kako unutarnja imigracija može utjecati na dohodovnu nejednakost: slučaj Italije promatran iz ekonomske i pravne perspektive}

Salvatore VILLANI, Luigi FERRARA, Giorgio LIOTTI Sveučilište u Napulju Federico II, Napuli, Italija

Mnogi znanstvenici trenutačno tvrde da migracija može imati važnu ulogu u smanjenju nejednakosti. To se već događalo, a moglo bi se ponoviti i u budućnosti, što je ne samo moguće nego i poželino. Međutim, pokretliivost stanovništva sama po sebi ne rješava pitanje nejednakosti. U najboljem slučaju, mogla bi je pomaknuti unaprijed, jer preraspodjela što je donosi useljavanje ne oslobađa od prethodnoga stvaranja osnovnoga skupa pravila i institucija, kojima je cilj poticati veliku suradnju među zemljama radi promjene zakonskih sustava upravljanja migracijama i korigiranja njihovih redistributivnih učinaka. U svjetlu tih studija, ovaj se rad usredotočuje na regionalni učinak unutarnjih migracija i pokušava pokazati, na primjeru Italije, kako iseljavanje može povećati dohodovne nejednakosti, čime se koči gospodarski rast, dok useljavanje može smanjiti dohodovne nejednakosti i ublažiti ekonomske neravnoteže. S pravnoga gledišta, 
DRUŠ. ISTRAŽ. ZAGREB GOD. 25 (2016), BR. 4, STR. $455-480$

VILLANI, S., FERRARA, L., LIOTTI, G.:

HOW INTERNAL... autori proučavaju regionalna ograničenja povezana sa zaštitom boravka radnika, slobodom kretanja europskih radnika i socijalnim naknadama za migrante.

Ključne riječi: dohodovna nejednakost, migracija, preraspodjela useljavanjem, administrativno državljanstvo za migrante

\section{(c) $(1) \Theta \Theta$}

Međunarodna licenca / International License:

Creative Commons Attribution-NonCommercial-NoDerivatives 4.0. 